\title{
JEKK
}

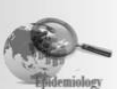

EI:T:

\section{Hubungan Tingkat Pengetahuan dan Sikap Ibu Hamil dengan Kepatuhan Kunjungan Antenatal Care Di Puskesmas Rijali Tahun 2021}

\author{
Ayu Betzia Mangosa*, Nathalie E.Kailola*, Ritha Tahitu*, Elpira Asmin* \\ *Bagian Ilmu Kesehatan Masyarakat Fakultas Kedokteran \\ Universitas Pattimura, Maluku
}

\begin{abstract}
Background: Antenatal Care (ANC) is a health service that is conducted to monitor and support the health of the mother and fetus and detect the presence of disorders during pregnancy and prevent complications. An ANC visits are said to be compliant if pregnant women make ANC visits at least six times. Anc's visit in Ambon City showed a decrease from 2019 to 2020. This study was conducted with the aim of finding out if there is a relationship between the level of knowledge and attitude of pregnant women with compliance with ANC visits at Rijali Health Center in 2021.

Method: This type of research is analytical with a cross-sectional approach with a sample number of 140 using consecutive sampling techniques. The analysis used in this study was a univariate and bivariate analysis using the chi-square test.

Results: The results of this study obtained the percentage of respondents who obediently conducted an ANC of $74.3 \%$ and non-compliant by $25.7 \%$.

Conclusion : Based on the results of the chi-square test there is a relationship between knowledge $(\mathrm{p}=0.007)$ and compliance with ANC visits at Rijali Health Center and there is no relationship between attitude $(\mathrm{p}=0.745)$ and compliance with ANC visits at Rijali Health Center. Thus this study demonstrates the importance of knowledge and attitude in carrying out an ANC visit.
\end{abstract}

Keywords: Antenatal Care; Knowledge; Attitude; Pregnant Women. 


\section{Pendahuluan}

Kehamilan adalah hal yang menyangkut perubahan fisiologi, biologi, dan psikis yang dapat mengubah hidup wanita. ${ }^{1}$ Proses alami dan fisiologis yang terjadi pada wanita ditandai dengan adanya fertilisasi yaitu proses pembentukan zigot dan akhirnya menjadi janin yang akan berkembang di dalam uterus sampai proses persalinan terjadi. ${ }^{2}$ Selama kehamilan, ibu hamil akan mengalami perubahan fisiologi dan psikologis sehingga membuat ibu hamil membutuhkan informasi dari petugas kesehatan mengenai ibu dan janin yang dikandungnya. Oleh karena itu, diperlukan pengawasan yang diberikan oleh tenaga kesehatan kepada ibu hamil. ${ }^{2,3}$

Salah satu indikator dalam mengukur derajat kesehatan adalah angka kematian ibu (maternal mortality rate). Menurut World Health Organization (WHO) ${ }^{4}$ kematian ibu adalah kematian wanita saat hamil atau dalam 42 hari setelah penghentian kehamilan yang terlepas dari durasi dan lokasi kehamilan dari penyebab apa pun yang terkait gangguan kehamilan atau penanganannya. Secara global data $\mathrm{WHO}^{5}$ tahun 2018 terdapat $47 \%$ kematian ibu akibat masalah persalinan atau kehamilan yang terjadi di negara berkembang. Pada tahun 2018 jumlah angka kematian ibu (AKI) di Association of Southeast Asian Nations (ASEAN) adalah 16.000/100.000 kelahiran hidup. Menurut Kementerian Kesehatan $\mathrm{RI}^{6}$ tahun 2018 terjadi penurunan AKI di Indonesia tahun 1991-2015 dari AKI 390 menjadi 305 per kelahiran hidup. Meskipun terjadi penurunan AKI tetapi masih belum mencapai target MDGs yaitu 102 per 100.000 kelahiran hidup. ${ }^{6}$

Salah satu upaya yang dapat dilakukan untuk menurunkan AKI dengan melakukan pelayanan kesehatan ibu yang berkualitas seperti kepatuhan kunjungan ANC. ${ }^{6}$ Menurut $\mathrm{WHO}^{7}$ tahun 2002 kunjungan ANC minimal dilakukan empat kali. Tahun 2020 kunjungan ANC diubah kembali oleh Kementerian Kesehatan $\mathrm{RI}^{8}$ menjadi enam kali hal ini dilakukan dengan tujuan untuk menurunkan angka kematian ibu dan bayi. Hasil pencapaian upaya kesehatan ibu hamil dapat dinilai dengan menggunakan indikator cakupan $\mathrm{K}_{1}$ dan $\mathrm{K}_{4} \cdot{ }^{9}$ Proporsi ibu hamil yang melakukan kunjungan ANC di Indonesia berdasarkan Laporan Riskesdas ${ }^{10}$ tahun 2018 yaitu $\mathrm{K}_{1}$ 96,1\% dan $\mathrm{K}_{4} 74,1 \%$. Provinsi Jawa tengah memiliki kunjungan $\mathrm{K}_{1}$ yang paling tinggi diantara provinsi yang lain yaitu 98,2\% sedangkan DI Yogyakarta memiliki kunjungan $\mathrm{K}_{4}$ yang tertinggi diantara provinsi yang lain yaitu 90,2\%. Kunjungan ANC di Provinsi Maluku berada pada urutan kedua terendah setelah Provinsi Papua dengan persentase $\mathrm{K}_{1}$ $85,9 \%$ dan $\mathrm{K}_{4} 47,9 \% .^{10}$

Menurut data dari Dinas Kesehatan Kota Ambon $^{11,12}$ kunjungan ANC tahun 2019 di Kota Ambon yaitu K1 55,1\% dan K4 68,7\%, dan terjadi penurunan tahun 2020 menjadi $\mathrm{K}_{1}$ $40 \%$ dan $\mathrm{K}_{4} 37 \%$. Kunjungan ANC di wilayah kerja Puskesmas Rijali tahun 2018 sebesar 95,2\% dan terjadi peningkatan pada tahun 2019 sebesar 106,6\% namun, tahun 2020 terjadi penurunan sebesar $73,3 \%$. Kunjungan keempat $\left(\mathrm{K}_{4}\right)$ di Puskesmas Rijali tahun 2018 yaitu $87,0 \%$ dan terjadi peningkatan pada tahun 2019 sebesar $92,7 \%$, tetapi pada tahun berikutnya terjadi penurunan kunjungan ANC menjadi $69,5 \%$. Puskesmas Rijali merupakan puskesmas dengan jumlah populasi ibu hamil yang besar di Kota Ambon dengan jumlah populasinya yaitu 1082 orang. Angka kunjungan ANC di Puskesmas Rijali telah mengalami peningkatan di tahun 2018-2019 dan terjadi penurunan yang cukup besar diantara puskesmas yang ada di Kota Ambon tahun 2020 yaitu $\mathrm{K}_{1} 40 \%$ dan $\mathrm{K}_{4} 37 \%$. $^{11,12}$

Target kunjungan ANC masih belum tercapai akibat kurangnya kepatuhan ibu hamil untuk melakukan kunjungan ANC, sehingga masih ada ibu hamil yang masih belum mengetahui pentingnya melakukan pemeriksaan selama kehamilan. Tingginya AKI dapat dipengaruhi oleh sikap ibu hamil dan didukung dengan pengetahuan ibu terhadap kehamilannya. ${ }^{13}$ Suatu penelitian yang dilakukan oleh Mujahida ${ }^{14}$ tentang Faktor-faktor yang mempengaruhi keteraturan pemeriksaan antenatal care di Puskesmas Biru-biru Kabupaten Bone didapatkan bahwa ibu yang patuh melakukan ANC sebesar $62,5 \%$ sedangkan yang tidak patuh sebesar $37,5 \%$. Berdasarkan analisis bivariat, variabel yang diuji dengan uji chi-square diperoleh 
nilai $p$ pada variabel pengetahuan yaitu $p=$ 0,000 dan variabel sikap yaitu $p=0,000$ yang berarti terdapat hubungan antara pengetahuan dan sikap dengan perilaku ANC. Berdasarkan masalah yang telah diuraikan maka peneliti tertarik untuk melakukan penelitian yang berjudul hubungan tingkat pengetahuan dan sikap ibu hamil dengan kepatuhan kunjungan ANC di Puskesmas Rijali Tahun 2021.

\section{Metode}

Penelitian ini merupakan penelitian analitik dengan pendekatan cross sectional, yang merupakan penelitian yang melakukan pengukuran pada variabel bebas dan terikat yang hanya satu kali pengukuran dalam satu waktu secara bersamaan. Penelitian telah dilakukan dari bulan Agustus-Oktober 2021 dan pengumpulan data dilakukan di Puskesmas Rijali. Populasi target dalam penelitian ini adalah semua ibu hamil yang berada di Kota Ambon. Populasi terjangkau dalam penelitian ini adalah ibu hamil yang memiliki usia kehamilan >24 minggu yang melakukan kunjungan ANC di Puskesmas Rijali dan berada ditempat saat dilakukannya penelitian. Teknik pengambilan sampel adalah Teknik consecutive sampling. Sampel penelitian adalah ibu hamil trimester III dengan usia kehamilan >24 minggu. Instrumen yang digunakan dalam penelitian ini adalah kuesioner yang telah dilakukan uji validitas dan reliabilitas oleh Siregar ${ }^{15}$ tahun 2013 dengan nilai cronbach alpha 0,836 dan Padesi $^{16}$ tahun 2020 dengan nilai cronbach alpha 0,767 .

Data dianalisis dengan menggunakan program Statistical Package for The Social Sciences (SPSS). Analisis univariat dilakukan untuk menjelaskan dan mendeskripsikan karakteristik dari tiap variabel. Analisis univariat dihasilkan jumlah dan persentase dari tiap variabel dengan menggunakan tabel. Analisis bivariat dilakukan untuk menilai adanya hubungan antara tingkat pengetahuan dan sikap dengan kepatuhan kunjungan ANC. Pada analisis bivariat uji yang digunakan adalah uji chi-square. Jika $p>a$ maka $\mathrm{H}_{0}$ diterima artinya tidak terdapat hubungan antara tingkat pengetahuan dan sikap ibu hamil dengan kepatuhan kunjungan ANC di
Puskesmas Rijali. Jika $p<a$ maka $\mathrm{H}_{0}$ ditolak artinya terdapat hubungan antara tingkat pengetahuan dan sikap ibu hamil dengan kepatuhan kunjungan ANC di Puskesmas Rijali. Sebelum responden mengisi kuesioner akan dijelaskan terlebih dahulu mengenai tujuan, manfaat dan prosedur penelitian dan meminta kesediaan responden untuk terlibat dalam penelitian.

\section{Hasil}

Tabel 1 tentang distribusi responden berdasarkan usia ibu hamil di Puskesmas Rijali diketahui persentase ibu hamil lebih banyak pada kelompok usia 20-35 tahun (90\%) dan persentase paling sedikit pada kelompok usia $<20 \operatorname{tahun}(9,3 \%)$.

Tabel 1 Distribusi responden berdasarkan usia ibu hamil di Puskesmas Rijali tahun 2021

\begin{tabular}{ccc}
\hline Usia & n & \% \\
\hline$<20$ tahun & 1 & 7 \\
20-35 tahun & 126 & 90 \\
$>35$ tahun & 13 & 9,3 \\
\hline Total & $\mathbf{1 4 0}$ & $\mathbf{1 0 0}$ \\
\hline
\end{tabular}

Tabel 2 tentang distribusi responden berdasarkan pendidikan ibu hamil di Puskesmas Rijali diketahui persentase ibu hamil lebih tinggi pada pendidikan perguruan tinggi $(50 \%)$ dan persentase pendidikan yang paling rendah pada pendidikan tamat SMP $(1,4 \%)$.

Tabel 2 Distribusi responden berdasarkan pendidikan ibu hamil di Puskesmas Rijali tahun 2021

\begin{tabular}{ccc}
\hline Pendidikan & n & \% \\
\hline Tamat SMP & 2 & 1,4 \\
Tamat SMA & 68 & 48,6 \\
Perguruan tinggi & 70 & 50 \\
\hline Total & $\mathbf{1 4 0}$ & $\mathbf{1 0 0}$ \\
\hline
\end{tabular}

Tabel 3 tentang distribusi responden berdasarkan paritas ibu hamil di Puskesmas Rijali diketahui persentase paritas paling tinggi pada multipara $(76,4 \%)$ dan persentase paling sedikit pada paritas grandemultipara $(0,7 \%)$. 
Tabel 3 Distribusi responden berdasarkan paritas ibu hamil di Puskesmas Rijali tahun 2021

\begin{tabular}{ccc}
\hline Paritas & n & \% \\
\hline Primipara (1 kali) & 32 & 22,9 \\
Multipara (>1 kali) & 107 & 76,4 \\
Grandemultipara (> & 1 & 0,7 \\
5 kali) & & \\
\hline Total & $\mathbf{1 4 0}$ & $\mathbf{1 0 0}$ \\
\hline
\end{tabular}

Tabel 4 tentang distribusi responden berdasarkan kepatuhan ANC di Puskesmas Rijali diketahui bahwa terdapat $(74,3 \%)$ lebih patuh melakukan ANC dan $(25,7 \%)$ tidak patuh melakukan ANC.

Tabel 4 Distribusi responden berdasarkan kepatuhan ANC di Puskesmas Rijali tahun 2021

\begin{tabular}{ccc}
\hline Kepatuhan ANC & n & \% \\
\hline Patuh & 104 & 74,3 \\
Tidak patuh & 36 & 25,7 \\
\hline Total & $\mathbf{1 4 0}$ & $\mathbf{1 0 0}$ \\
\hline
\end{tabular}

Tabel 5 tentang distribusi responden berdasarkan pengetahuan ibu hamil di Puskesmas Rijali diketahui persentase pengetahuan ibu hamil lebih tinggi pada kategori baik $(49,3 \%)$.

Tabel 5 Distribusi responden berdasarkan pengetahuan ibu hamil di Puskesmas Rijali tahun 2021

\begin{tabular}{ccc}
\hline $\begin{array}{c}\text { Tingkat } \\
\text { pengetahuan }\end{array}$ & n & \% \\
\hline Baik & 69 & 49,3 \\
Cukup & 57 & 40,7 \\
Kurang & 14 & 10 \\
\hline Total & $\mathbf{1 4 0}$ & $\mathbf{1 0 0}$ \\
\hline
\end{tabular}

Tabel 6 tentang distribusi responden berdasarkan sikap ibu hamil di Puskesmas Rijali diketahui persentase sikap ibu hamil lebih tinggi pada kategori baik (85\%).
Tabel 6 Distribusi responden berdasarkan sikap ibu hamil di Puskesmas Rijali tahun 2021

\begin{tabular}{ccc}
\hline Sikap & n & \% \\
\hline Baik & 119 & 85 \\
Kurang baik & 21 & 15 \\
\hline Total & $\mathbf{1 4 0}$ & $\mathbf{1 0 0}$ \\
\hline
\end{tabular}

Tabel 7 tentang hasil analisis hubungan pengetahuan dengan kepatuhan kunjungan ANC di Puskesmas Rijali menggunakan uji Chi-square. Terdapat hubungan yang signifikan antara pengetahuan dengan kepatuhan kunjungan ANC di Puskesmas Rijali dengan nilai $(p=0,007)$.

Tabel 7 Hubungan pengetahuan dengan kepatuhan kunjungan ANC di Puskesmas Rijali tahun 2021

\begin{tabular}{|c|c|c|c|c|c|c|c|}
\hline \multirow{3}{*}{ Pengetahuan } & \multicolumn{4}{|c|}{$\begin{array}{c}\text { Kepatuhan } \\
\text { melakukan ANC }\end{array}$} & \multirow{2}{*}{\multicolumn{2}{|c|}{ Total }} & \multirow{3}{*}{$p$} \\
\hline & \multicolumn{2}{|c|}{ Patuh } & \multicolumn{2}{|c|}{$\begin{array}{l}\text { Tidak } \\
\text { patuh }\end{array}$} & & & \\
\hline & $\mathrm{n}$ & $\%$ & $\mathrm{n}$ & $\%$ & $\mathrm{n}$ & $\%$ & \\
\hline Baik & 57 & 82,6 & 12 & 17,4 & 69 & 100 & \multirow{4}{*}{0,007} \\
\hline Cukup & 41 & 71,9 & 16 & 28,1 & 57 & 100 & \\
\hline Kurang & 6 & 42,9 & 8 & 57,1 & 14 & 100 & \\
\hline Total & 104 & 74,3 & 36 & 25,7 & 140 & 100 & \\
\hline
\end{tabular}

Hasil analisis hubungan sikap dengan kepatuhan kunjungan ANC di Puskesmas Rijali menggunakan uji chi-square. Tabel 8 menunjukan tidak terdapat hubungan yang signifikan antara sikap dengan kepatuhan kunjungan ANC di Puskesmas Rijali dengan nilai $(p=0,745)$.

Tabel 8 Hubungan sikap dengan kepatuhan kunjungan ANC di Puskesmas Rijali tahun 2021

\begin{tabular}{|c|c|c|c|c|c|c|c|}
\hline \multirow{3}{*}{ Sikap } & \multicolumn{4}{|c|}{$\begin{array}{c}\text { Kepatuhan } \\
\text { melakukan ANC }\end{array}$} & \multirow{2}{*}{\multicolumn{2}{|c|}{ Total }} & \multirow{3}{*}{$p$} \\
\hline & \multicolumn{2}{|c|}{ Patuh } & \multicolumn{2}{|c|}{$\begin{array}{l}\text { Tidak } \\
\text { patuh }\end{array}$} & & & \\
\hline & $\mathrm{n}$ & $\%$ & $\mathrm{n}$ & $\%$ & $\mathrm{n}$ & $\%$ & \\
\hline Baik & 89 & 74,8 & 30 & 25,2 & 119 & 100 & \\
\hline $\begin{array}{c}\text { Kurang } \\
\text { baik }\end{array}$ & 15 & 71,4 & 6 & 28,6 & 21 & 100 & 0,745 \\
\hline Total & 104 & 74,3 & 36 & 25,7 & 140 & 100 & \\
\hline
\end{tabular}




\section{Pembahasan}

Penelitian ini, sebagian besar responden yang patuh melakukan ANC adalah responden yang memiliki pengetahuan baik sedangkan yang tidak patuh melakukan ANC lebih tinggi pada responden yang memiliki pengetahuan kurang. Berdasarkan analisis data diketahui terdapat hubungan yang signifikan antara pengetahuan dengan kepatuhan kunjungan ANC di Puskesmas Rijali. Ibu hamil yang memiliki pengetahuan yang baik akan patuh dalam melakukan kunjungan ANC karena ibu hamil ingin menjaga kesehatan ibu dan janin serta jika ada kelainan akan cepat mendapat pertolongan. Menurut Notoatmodjo ${ }^{17}$ pengetahuan merupakan salah satu faktor yang dapat mempengaruhi perubahan perilaku. Seseorang yang memiliki pengetahuan yang baik, maka akan memiliki motivasi diri untuk mengaplikasikan dalam kehidupannya. Pengetahuan mengenai kehamilan dapat diperoleh melalui penyuluhan tentang kehamilan, pertumbuhan dan perkembangan janin, perawatan diri selama kehamilan, serta tanda bahaya yang harus diwaspadai selama kehamilan. ${ }^{18}$ Berdasarkan hasil penelitian dapat dilihat bahwa terdapat responden yang memiliki pengetahuan yang baik tetapi tidak patuh melakukan ANC.

Mubarak $^{19}$ menyatakan faktor yang mempengaruhi pengetahuan adalah usia, pendidikan, pengalaman dan informasi. Persentase usia pada penelitian ini lebih banyak pada usia 20-35 tahun, usia tersebut merupakan usia yang memiliki tingkat berfikir lebih rasional dibandingkan dengan usia yang masih muda. Dengan bertambahnya usia maka, pengetahuan yang dimiliki oleh seseorang akan meningkat. Paritas ibu hamil di Puskesmas Rijali lebih tinggi pada multipara (sudah menjalani kehamilan $>1$ kali). Hal ini disebabkan karena responden yang sudah menjalani kehamilan sebelumnya mereka sudah mengetahui bagaimana menjaga kesehatan ibu dan janin. Selain itu, responden yang mendapat informasi lebih banyak dari media seperti internet dan televisi. Mayoritas pendidikan ibu hamil adalah berpendidikan tinggi namun masih banyak juga yang berpendidikan SMA. Hal ini menunjukan semakin tinggi pendidikan seseorang maka pengetahuan yang dimiliki semakin baik. Hal ini sejalan dengan teori Wawan $\mathrm{dkk}^{20}$ bahwa semakin tinggi pendidikan seseorang maka semakin mudah untuk mendapatkan informasi. Hasil penelitian menunjukan responden yang tidak patuh melakukan ANC adalah responden yang memiliki pengetahuan kurang. Hal ini sejalan dengan teori Green ${ }^{21}$ yaitu pengetahuan yang kurang maka pelayanan kesehatannya juga cenderung kurang baik. Hasil penelitian sejalan dengan penelitian Safitri $\mathrm{dkk}^{22}$ yang menyatakan semakin baik pengetahuan ibu hamil maka kunjungan ANC yang dilakukan sesuai dengan standar yang ditetapkan.

Hasil penelitian menunjukan mayoritas responden yang patuh melakukan ANC adalah responden yang memiliki sikap baik dan yang tidak patuh melakukan ANC lebih tinggi pada sikap kurang baik. Menurut Notoatmodjo ${ }^{17}$ sikap merupakan tindakan, persepsi, atau pola pikir yang dilakukan dalam menghadapi suatu objek atau situasi. Berdasarkan analisis data tidak terdapat hubungan yang signifikan antara sikap dengan kepatuhan kunjungan ANC di Puskesmas Rijali. Hal ini disebabkan karena responden yang masih takut untuk memeriksa kehamilan di masa pandemi COVID-19, tidak tercatatnya kunjungan di buku KIA saat melakukan pemeriksaan kehamilan di dokter spesialis dan responden yang memeriksa kehamilan disaat ada keluhan dengan kehamilannya saja. Hal ini didukung oleh teori Kemenkes $\mathrm{RI}^{23}$ bahwa adanya pandemi COVID-19 membuat semua pelayanan kesehatan menjadi terdampak termaksud pelayanan kesehatan ibu dan anak. Selain itu teori dari Herlon, Masjid dan Rasma ${ }^{24}$ yang menyatakan bahwa ibu hamil yang memanfaatkan pelayanan kesehatan saat adanya keluhan selama kehamilan. Ibu hamil yang mengalami keluhan maka ibu hamil akan lebih sadar untuk memanfaatkan pelayanan kesehatan sehingga kesehatan mereka dan janin menjadi lebih baik atau tidak lebih menjadi buruk. Hasil penelitian ini sejalan dengan penelitian Azizah $\mathrm{dkk}^{25}$ bahwa ibu hamil yang takut tertular COVID-19 saat melakukan pemeriksaan kehamilan. Penelitian lain dilakukan oleh Dewi $\mathrm{dkk}^{26}$ terdapat ibu hamil yang memiliki sikap baik tetapi tidak 
patuh karena ibu tidak melaporkan saat memeriksa kehamilan di dokter spesialis sehingga tidak tercatat pada buku KIA.

\section{Kesimpulan}

Hasil penelitian ini menemukan bahwa tingkat pengetahuan berhubungan dengan kepatuhan kunjungan ANC pada ibu hamil di Puskesmas Rijali. Sedangkan temuan lain menyatakan bahwa tidak terdapat hubungan antara sikap dengan kepatuhan kunjungan ANC Ibu hamil di Puskesmas Rijali.

\section{Ucapan Terima Kasih}

Terima kasih kepada JEKK yang telah mengizinkan penulis untuk memodifikasi template yang telah dikembangkan.

\section{Daftar Pustaka}

1. Maulana M. 2016. Panduan lengkap kehamilan. Cetakan 2. Yogyakarta : Kata hati.

2. Febyanti NK, Susilawati D. 2012. Hubungan pengetahuan ibu hamil tentang antenatal care terhadap perilaku kunjungan kehamilan. Soedirman J Nurs. 2012;7(3):148-57.

3. Wahyuningsih A, Palupi KD. 2020. Kepatuhan kunjungan antenatal care pada ibu di wilayah kerja Puskesmas Pesantren II Kota Kediri. Jurnal penelitian keperawatan. 2020;6(1).

4. World Health Organization. 2015. Trends in maternal mortality: 1990 to 2015. Geneva.

5. World Health Organization. 2018. World health statistics : Monitoring health for the SDGs. 2018: 227-249.
6. Kemenkes RI. 2018. Profil kesehatan Indonesia 2018 [Indonesia Health Profile 2018] [Internet]. 2019. 207 p. Available from: http://www.depkes.go.id/resources/ download/pusdatin/profil-kesehatanindonesia/Data-dan-Informasi_ProfilKesehatan-Indonesia-2018.pdf.

7. WHO. 2016. WHO recommendation on antennal care for a positive pregnancy experience. [Internet]. Available from:https://apps.who.int/iris/bitstream/h andle/10665/250796/9789241549912eng. pdf;jsessionid=6ED8C3C4A63AEB0C4E D35471DC2A31C4? sequence $=1$.

8. Pranoto P. 2012. Ilmu kebidanan. Yogyakarta: Yayasan Bina Pustaka. Sarwono.

9. Kementerian Kesehatan RI. 2010. Pedoman pelayanan antenatal terpadu. Jakarta: Kementerian Kesehatan Direktur Jenderal Bina Kesehatan Masyarakat.

10. Riskesdas. 2018. Laporan nasional riskesdas 2018. Jakarta: Lembaga penerbit badan penelitian dan pengembangan kesehatan.

11. Dinas Kesehatan Kota Ambon. 2020. Profil kesehatan Kota Ambon tahun 2019. Ambon: Dinkes Kota Ambon.

12. Dinas Kesehatan Kota Ambon. 2021. Profil kesehatan Kota Ambon tahun 2020. Ambon: Dinkes Kota Ambon.

13. Prataumi ES. 2019. Pengetahuan dan sikap ibu hamil dalam kunjungan antenatal care di klinik abi ummi DW Sarmadi Palembang. J Midwifery Nurs.1(3):12-7.

14. Mujahidah FF. 2020. Faktor-faktor yang mempengaruhi keteraturan pemeriksaan antenatal care di Puskesmas Biru-biru Kabupaten Bone. Jurnal Ilmu Kesehatan. 2(1):30-5. 
15. Siregar N. 2013. Faktor-faktor yang memengaruhi pemanfaatan pelayanan antenatal care di wilayah kerja Puskesmas Sosopan Kabupaten Padang Lawas tahun 2012. [Tesis]. Medan: Fakultas kesehatan masyarakat Universitas Sumatera Utara.

16. Padesi NLW. 2020. Hubungan pengetahuan tentang kunjungan Antenatal care dengan keteraturan kunjungan antenatal care ibu hamil trimester III di masa pandemic COVID-19 [Skripsi]. Denpasar: Politeknik kesehatan Kemenkes Denpasar jurusan kebidanan.

17. Notoatmodjo. 2012. Soekidjo. Metodologi Penelitian Kesehatan Edisi 2. Jakarta: Jakarta Rineka Cipta.

18. Lestari. 2015. Kumpulan Teori Untuk Kajian Pustaka Penelitian Kesehatan. Yogyakarta: Nuha Medika.

19. Mubarak WI. 2007. Promosi kesehatan: Sebuah pengantar proses belajar mengajar dalam pendidikan. Yogyakarta: Yogyakarta Graha Ilmu.

20. Wawan, Dewi. 2017. Teori dan pengukuran pengetahuan, sikap dan perilaku manusia. Yogyakarta: Nuha media.
21. Green LW. 2002. Health Education Planning, 'A Diagnostic Approach'. Mayfield Publishing Company: California.

22. Safitri Y, Lubis DH. 2020. Dukungan suami, pengetahuan, dan sikap ibu hamil terhadap kunjungan antenatal care. J Kebidanan Malahayati. 6(4):413-20.

23. Kementerian Kesehatan RI. 2020. Pedoman pelayanan antenatal, persalinan, nifas, dan bayi baru lahir di Era Adaptasi Baru: 98.

24. Heron HA, Masjid R, Rasma. 2017. Faktor yang berhubungan dengan pemanfaatan antenatal care pada ibu hamil di wilayah kerja Puksesmas Katobu Kabupaten Muna tahun 2016. JIMKESMAS.2(6):1-10.

25. Azizah, Ruslinawati H, Wulandatika D. 2021. Faktor-faktor yang berhubungan dengan frekuensi kunjungan antenatal care pada ibu hamil masa pandemi covid19 di Puskesmas Pekauman Banjarmasin. J Midwifery Reproduct. 5(1): 1-9.

26. Dewi Ciselia, Vivi Oktari. 2020. Hubungan pengetahuan dan sikap Ibu dengan kelengkapan kunjungan antenatal care di Puskesmas Kenten Palembang tahun 2019. J Kebidanan J Med Sci Ilmu Kesehat Akad Kebidanan Budi Mulia Palembang. 10(2):18-21. 